\title{
Humanitarian Crisis and the Arduous Path to Principled Pluralism: A Politico-Theological Analysis on Indian and Turkish Foreign Policies (2014-2019)
}

\author{
Hadza Min Fadhli Robby \\ Department of International Relations, Faculty of Psychology \\ and Socio-Cultural Sciences \\ Islamic University of Indonesia, Yogyakarta \\ Email: hadza.fadhli@uii.ac.id
}

\begin{abstract}
This research aims to analyze the influence of political theology in the foreign policy of Indian and Turkish from 2014 to 2019. India and Turkey used political theology as one of the essential considerations for the conduct of foreign policies during the humanitarian crisis. Both countries were trying to conduct "politics of salvation" to protect their fellow faithful from the oppression in the neighboring regions. While conducting its politics of salvation in their foreign policies, India and Turkey were trying to protect their fellow faithful from the oppression from the constructed others. This research argues that the politics of salvation in its foreign policy will influence both countries' religious freedom and secularism. This research would like to utilize the concept of "politics of principled pluralism" that Robert Joustra developed. In its analysis, this research engages with several articles from news outlets and research journals to construct arguments on the conduct of the foreign policy of India and Turkey in times of humanitarian crisis. This research found that India and Turkey had tried to implement their version of "politics of salvation" that deteriorate religious freedom and inclusive democracy.
\end{abstract}

Keywords: humanitarian crisis, India, Turkey, political theology in international relations, politics of principled pluralism 


\begin{abstract}
Abstrak
Riset ini bertujuan untuk mengkaji pengaruh pemahaman teologi politik pada politik luar negeri India dan Turki. India dan Turki telah dipiilh sebagai studi kasus dalam riset ini karena kedua negara telah mengalami sekularisme dalam waktu yang cukup lama. Proses sekularisme itu diikuti oleh adanya kebangkitan politik keagamaan sebagai sebuah upaya untuk melawan sekularisasi. India dan Turki menggunakan pemahaman teologi politik sebagai salah satu pertimbangan esensial dalam menjalankan politik luar negeri, terutama saat menghadapi krisis kemanusiaan. Kedua negara menjalankan apa yang disebut sebagai 'politik penyelamatan' untuk melindungi sesama pemeluk agama dari tindakan opresif para "liyan" di kawasan sekitar. Saat menerapkan 'politik penyelamatan' tersebut, India dan Turki mencoba untuk melindungi sesama pemeluk agamanya dari kezaliman liyan yang dikonstruksi oleh India dan Turki. Riset ini berargumen bahwa praktik politik penyelamatan di dalam politik luar negeri India dan Turki akan mempengaruhi posisi kedua negara dalam isu kebebasan agama serta sekularisme. Riset ini akan menggunakan konsep politik pluralisme berprinsip yang dikembangkan oleh Robert Joustra. Riset ini menemukan bahwa India dan Turki telah mencoba untuk menerapkan politik penyelamatan sesuai dengan versi masing-masing, namun penerapan politik penyelamatan tersebut berdampak buruk terhadap kebebasan beragama dan demokrasi inklusif.
\end{abstract}

Kata Kunci: krisis kemanusiaan, India, Turki, teologi politik dalam hubungan internasional, politik pluralisme berprinsip

\section{INTRODUCTION}

Haynes argued at least two types of interactions between religion and foreign policy (Haynes, 2014). The first interaction which Haynes identified is that religious values could consistently drive foreign policy. This interaction could be seen mostly in countries established under particular religious values or principles. The second interaction is the recurrent centrality of religious concerns in the foreign policies of several countries. With the categorization explained above, this paper would like to discuss the foreign policies of two separate countries, India and 
Turkey, in the humanitarian crisis and how it would have affected the effort of both countries to construct principled pluralism.

India and Turkey were used as case studies in this paper because both countries are well-known for their adherence to the secular political system. While Turkey has seen the ascent of the AK Party in Turkey contribute to the resurgence of conservative ideas amid neoliberal authoritarianism, India witnessed the rise of BJP in India, eventually leading to a re-interpretation and re-reading of the principle of secularism that was already enshrined in the Constitution of the Republic of India since 1976. While developing their new narratives on secularism, both countries are also trying to strengthen their selfidentity. This effort to strengthen self-identity influenced the foreign policies of both India and Turkey. India and Turkey used religious pretexts and principles to strengthen their self-identity when faced with a humanitarian crisis.

In the case of Turkey, Turkey is facing a hostile engagement with its closest neighbor, Syria. During the implementation of an opendoor policy to welcome refugees and political oppositions from Syria. During the Syrian Civil War, by accepting the pro-democratic Sunni Muslim refugees, Turkey is trying to build a straightforward narrative to become a savior for (pro-democratic) Sunni Muslims in Syria and the Middle East (Kloos, 2016, p. 551). In the case of India, India seeks to protect the persecuted Hindu, Buddha, Sikh, Parsi and Christian adherents from the discriminatory policies implemented by the governments and societies of Bangladesh, Afghanistan and Pakistan (Khan, 2020, p.3). In this paper, the case of Turkish and Indian involvement in the humanitarian crisis will be discussed and compared in detail. This research aims to find the connection between the foreign policies of India and Turkey with pretexts and justifications based upon religious values and texts to respond toward imminent dangers of the humanitarian crisis that would affect coreligionists' lives in neighboring countries regions. Looking at how both countries tried to show themselves as the protector of refugees, Turkey and India try to conduct their "politics of salvation".

\section{THEORETICAL FRAMEWORK AND RESEARCH METHOD}

Robert Joustra, in his monumental work on religion and 
foreign policy, tried to elaborate on the importance of positioning political theology correctly in contemporary international politics. Joustra clarified that it is essential to settle the definition of political theology before further analyzing the relations between political theology and foreign policy. According to Joustra, political theology is an understanding and practice that political actors have about the meaning of and the relationship between the religious and the secular and what constitutes legitimate political authority. Referring to his definition of political theology, Joustra made the following table to explain the differing interpretation of the relations between religion and secular affairs in public affairs (Joustra, 2018).

Table 1 Rival versions of the religious and the secular in public affairs

\begin{tabular}{|c|c|c|c|c|}
\hline \multirow[b]{2}{*}{ Versions } & \multicolumn{4}{|c|}{ Political theology understanding } \\
\hline & $\begin{array}{l}\text { Understanding } \\
\text { and practice of } \\
\text { the religious }\end{array}$ & $\begin{array}{l}\text { Understanding } \\
\text { and practice of } \\
\text { the secular }\end{array}$ & $\begin{array}{l}\text { Relationship } \\
\text { between religious } \\
\text { and secular }\end{array}$ & $\begin{array}{l}\text { What } \\
\text { constitutes } \\
\text { legitimate } \\
\text { political } \\
\text { authority? }\end{array}$ \\
\hline $\begin{array}{l}\text { Principled } \\
\text { Secularism/ } \\
\text { Principled } \\
\text { Pluralism }\end{array}$ & $\begin{array}{l}\text { Essentially } \\
\text { contested }\end{array}$ & $\begin{array}{l}\text { Mutual } \\
\text { resonance, } \\
\text { overlapping } \\
\text { consensus } \\
\text { (limited by } \\
\text { "constitutive } \\
\text { values of } \\
\text { liberal } \\
\text { democracy." }\end{array}$ & $\begin{array}{l}\text { Like other } \\
\text { reasoning, } \\
\text { principled } \\
\text { pluralism should } \\
\text { be part of the } \\
\text { rationale by } \\
\text { which political } \\
\text { actors agree } \\
\text { on secular } \\
\text { policy (mutual } \\
\text { resonance). The } \\
\text { state does not } \\
\text { monopolize the } \\
\text { logic by which } \\
\text { actors arrive at a } \\
\text { consensus. }\end{array}$ & $\begin{array}{l}\text { Legitimate } \\
\text { political } \\
\text { authority is } \\
\text { constituted } \\
\text { by secular } \\
\text { principles } \\
\text { that } \\
\text { emerge in } \\
\text { overlapping } \\
\text { consensus } \\
\text { from political } \\
\text { actors, not by } \\
\text { rationale by } \\
\text { which actors } \\
\text { arrive at them }\end{array}$ \\
\hline
\end{tabular}

Adopted from Joustra with several adjustments (2018, pp. xiii-xiv ) 
Joustra considered principled pluralism to be a practical framework that could reflect upon the role of foreign affairs in a post-secular global order. Joustra also argued that principled pluralism needed to be based upon the advancement of strong public principles that should not be followed by monopolizing public logic. Therefore, there is a need for both secular and religious actors to establish their position and 'full rationales' to pursue a politics of non-conflictual coexistence, diversity and mutual understanding, especially between groups with opposing worldviews. Joustra emphasized the importance of compromise between two extreme choices of ontological exclusivism (as strived by right-wing extremists) and cosmopolitan paralysis (as pursued by liberals) (Joustra, 2018, p.86).

This paper would engage with Joustra's construction on political pluralism to see whether the humanitarian crisis in India and Turkey could strengthen the idea of principled pluralism or otherwise. India and Turkey are currently experiencing the conservative turn and strong homogenization of their society. This paper will also analyze the development of secularism in both countries, how it eventually transformed, and how the transformation would affect public affairs, including the foreign policies of both countries in responding to the humanitarian crisis.

This research used two case studies separately in Turkey and India to better understand the usage of religious pretexts in global politics. This research also methodologically referred to the qualitative research method. During the analysis process, only data from research journals and news articles were used. The data gathered during the literature research was analyzed with conceptual frameworks that had been thoroughly elaborated in the above paragraphs. The theory will be used in the analytical phase of this research by first explaining the study cases and then correlating the study cases with one of the categories explained in the table above.

\section{RESULTS AND EXPLANATION}

The Roots of Political Theology in Modern India and Turkey

Although India was founded formally as a "secular" state, India founded its political foundation upon the heritage of the Dharmic (Hindu-Buddha) civilization. During the discussions on which flag and the national symbol should 
India used, the founding fathers of India did agree that the flag and the national symbol of India would be taken from the symbols of the great Mauryan Dynasty that was ruled by a just king who had united the land of India, Ashoka. The Constituent Assembly of India adopted the Swaraj flag used since the era of the independence movement by replacing the charkha (spinning wheel) with Ashoka Chakra (the wheel of Ashoka). According to Radhakrishnan, the Ashoka Chakra represents the commitment of the Indian government to always abide by the eternal law of dharma and be able to adapt to peaceful change (MHA Government of India, 2002). The state emblem of India is also adapted from the Lion Capital of Ashoka. Even though India is a nation that consists of many nations and religions, the Hindu-Buddha philosophical value became India's political and moral foundation.

According to Vajpeyi, the political foundations of India are based on six central values. These five values consist of ahimsa, viraha, samvega, dharma, artha and duhkha. These values were reflected by India's founding fathers and prominent spiritual figures, namely Gandhi, the Tagore Brothers (Abanindranath and Rabindranath Tagore), Nehru and Ambedkar. These philosophical values were being constructed to find a new way of understanding the true Self of India, particularly after India gained its independence. These founding fathers reflected upon the religious texts from the Hindu-Buddha tradition and contextualized that text into the reality of the $20^{\text {th }}$ century. These five values are instrumental to reaching the eventual goal of true swaraj, which is self-governance by the Indian people. Swaraj, in this context, could not only be defined as a formalized transfer of power and sovereignty from colonizing power to the colonized. Instead, swaraj needs to be understood as a condition in which suffering experienced by a human would be transformed and transcended to have the independence to make themselves (Vajpeyi, 2012, p.38).

In her book, Vajpeyi tried to explain each of these philosophical values. Being promoted by Gandhi, Ahimsa is often being translated equally to the meaning of "doing nothing" or "passivism". Instead of promoting "passivism", Gandhi preached ahimsa as an art of resistance by minimizing any potential of violence. According to Vajpeyi, Gandhi's ahimsa belief was originated not from the Jain 
tradition but instead from Gandhi's interpretation of the Bhagavad Gita. On the value of viraha, Vajpeyi elaborated the thought of Rabindranath Tagore on the divided Self of India. Viraha, defined as a self's longing, became the origin of conflict and suffering in the Indian subcontinent. Tagore argued that Viraha is caused by the Western interpretation of nationalism which is not suitable to Indic culture. Abanindranath Tagore had shown his reflection of this struggle of India's Self through his painting and artworks. Mentioning Tagore's well-known artwork on Shah Jahan, Vajpeyi saw that Tagore described India's divided Self through samvega - a shock that enables someone to rediscover itself. As a symbol of convergence between Hindu and Muslim identity, Shah Jahan was portrayed by Tagore to describe a unity of divergent identities (Vajpeyi, 2012 pp. 130-134).

Vajpeyi also reminded the importance of Nehru's thought on Indian moral philosophy. It is important to note that Nehru's thought is often related to the idea of secularism. However, this credential did not prevent Nehru from reflecting upon the legacies of Indian ancient philosophical works written by Kautilya. The value of dharma (self-aspiration) and artha (self-purpose) eventually inspired Nehru to discover his version of India's Self. His exploration of these two values also became why he chose to adopt the symbols of the Ashokan Empire. The meditation and reflection of Ambedkar on the teaching of Buddha drive Ambedkar to believe that the essence of political activism in India is to ensure that people's suffering (duhkha) can be alleviated. Thus, as one of the principal drafters of the Indian Constitution, Ambedkar elaborated many principles that provide positive discriminations toward those who have been suffering all their lives, such as religious minorities, backward castes, and backward tribal communities. All these values, according to Vajpeyi, have been instrumental in creating modern India. Many political groups from various ideologies in India still take these values as principal values in their political conduct (Vajpeyi, 2012).

The discovery of the Indian Self has been an arduous and uneasy journey. What constitutes Self of India is still being discussed continuously by various political ideologies in India. Several politicians and political groups, such as Indian National Congress, 
are still asserting their commitments to the secular credentials. However, many political parties and groups that are affiliating themselves to the idea of Hindutva are criticizing secular values. According to Clarke (2002), the idea of Hindutva seeks to strengthen the political ground of Hindu nationalists in India by employing two tactics: first, persuading minorities (particularly Christians) as targets to be included as part of the united Hindu community and second, applying coercive means to pressurize people who are resisting against movements for the pan-Hindu identity (Clarke, 2002, p.207).

Hindutva gained more popularity from the Indian populace by promoting Integral Humanism, which was inspired by the principle of Sarvarkar's and Golwalkar's Hindu Nationalism and the strong tendency of a corporatist socialpolitical philosophy. As a founder of Integral Humanism, Deendayal Upadhyaya (an RSS member and the founder of Jana Sangh) argued that India should construct its social order as an organic unity organized under the greater principle of dharma. The dharma will guide people to obtain their needs of artha (political and economic need) and kama (bodily desire) and to finally reach moksha (liberation of the soul from the body) (Bhatt \& Mukta, 2000, p.420). According to Upadhyaya, a dharmic society is essential for creating an Indian society free of conflict and contradiction (Sharma \& Nain, 2018, p. 18). Consequently, Hindu nationalists argue that NonHindu minorities must undergo a process of assimilation to the Hindu way of life. Golwalkar, also known as Guruji, even emphasized the importance of adopting and assimilating the Hindu culture and language by foreign races in India. Golwalkar further argued that the original identities of these "foreign races" must be subordinated to the grander idea of the Hindu nation (Golwalkar, 1939, pp. 104-105).

From the elaboration above, the understanding of the true Indian Self heavily relies on how the Indian politicians see the diverse and divergent nature of the Indian Self. The tragic episodes of the HinduMuslim conflicts, such as the 1947 Great Partition and the Aligarh riots in India, had made the Indian Selfunderstood as an exclusivist idea that could only be claimed by those who are willing to adopt the Hinduness. The true Self of India, according to Hindu nationalists, could only be explored by Hindus. Thus, according to this interpretation, it could be 
concluded that those who are not willing to understand the true Self of India through the reading of Hindu philosophy would not be able to claim themselves as a true Indian.

Similar to the context of Indian politics, the political history of modern Turkey has been marked by a never-ending quest to find the true Turkish Self, which is trapped between two distinct identities of West and East. The early quest to find the true Turkish Self in the modern era has begun in II. Meşrutiyet Dönemi (Second Constitutional Era), when Ottoman Turkey was facing several episodes of political crisis. Some Ottoman Turks who were educated with Western curriculum tried to re-evaluate the meaning of being a Turk and thus tried to create a new conception of Turkey (Weiker, 1968). After the fall of the Ottoman Empire in 1923, the modernization efforts continued and brought significant change to Turkey's understanding of religious life. According to Çelik (2018), Mustafa Kemal Atatürk to implement the laiklik (laicism a la Turkey) does not entirely separate the secular from the religion. Atatürk understood that most Turkish people at that time considered religion as something dear to their life. Instead of imposing a total separation of religion from the daily life of Turkish people, Atatürk seeks to control the religious life in Turkey and reduce the presence of religion in the Turkish public sphere. It is under the Atatürk regime that Sunni Islam was controlled under the authority of Diyanet Isşleri Reişliği (The Presidency of Religious Affairs, now also known by the name of Diyanet İsleri Başkanlı̆̆ı).

The logic of political theology of Atatürk's secularism is based on the intention of Atatürk to modernize the teaching and understanding of Islam in Turkish society. In this context, Turkish secularism could be defined as an effort to change Western assumptions about Turkish Muslims radically and to suit the portrayal of Turkish Muslims to the standard of a modern Western citizen. Another essential aspect that needs to be looked upon in the process of secularisation in Turkey is the rationalization and Turkification of Islam (Azak, 2008, pp. 166-169). Atatürk mentioned that Islam should be a rational religion that the general public could easily understand. He also emphasized the importance of indigenizing the religion to ensure that the religion is suitable to the nation-building agenda in Turkey. Therefore, several policies, such as changing the liturgical language 
from Arabic to Turkish was pursued by Atatürk's government. It is argued that the indigenization of Islam was a project that eventually would help Islam be re-interpreted according to the need of modern Turkish society (Altunışık, 2005 p. 47). Thus, it would help Turkish people hold firmly to religion while at the same time progressing economically and politically.

Several parties have initiated the effort to bring religion back to the political stage, but Said Nursi initiated the effort to rejuvenate religious life in secularised and modernized Turkey. Said Nursi challenged the idea of top-down secularisation enacted by Atatürk's government. Nursi thought that Islam could and should guide the populace in facing the modern world. The key to facing the modern world, according to Nursi, is to have a balanced understanding of secular and religious science (Kuru \& Kuru, 2008). Another wave of critics towards secularism also came from various religious and conservative political figures, such as Nurettin Topçu, Zahid Kotku and Necip Fazıl Kisakürek, argued that there should be a renewal in the Turkish politics and society by returning to the cultural and civilizational heritage of Turkey (Guida, 2014; Mardin,
2005, p. 155). Although Topçu and Kisakürek were mainly educated in a Western and secular educational system, they were the ones who drove a new movement of political Islam and conservatism that tried to evaluate and even to challenge the dominance of secularism itself. With regards to Kotku, as a religious cleric, he emphasized how to provide religious education to the students of the secular institutions so that these religiously educated students would become ranking politicians and change the course of Turkish politics (Alam, 2009). These thinkers would inspire a new stream of political Islamism and change Turkey's thought stream of political theology.

Under the regime of AK Parti, the understanding of political theology was envisioned in a new way, but not by totally forsaking the conception of Turkish secularism. According to Öztürk (2019)the Turkish state and the ruling Justice and Development Party (AKP, AK Parti had made ethnoreligious desires and power-based conflicts ever more dominant in Turkey. As a result, Öztürk argued that Turkey has transformed into a country with inclusionary and hegemonic-authoritarian political characters. This transformation 
has allowed Sunni Islam to take one of the regime's critical focal points. Öztürk's argument was also confirmed by Tepe (2016), who said that the existence of Diyanet as a distinct product of Turkish secularism had opened channels for debates and discourse on the understanding of religious and political theology in Turkey. At the same time, Diyanet in recent times also strengthened the hegemony of AK Parti. Kaya also brought another argument, Robert \& Tecmen (2020), who argued that populism in Turkey under AK Parti (as well as in the case of National Front in France) had defended the superiority of nativism by reviving the Ottoman Turkish identity, the suspicions toward the value of multiculturalism, and the skepticism toward the European Union.

\section{The Conduct of Politics of Salvation in India and Turkey}

In 2019, the Indian government started a new debate to amend the existing Citizenship Act. As stipulated in the Citizenship Amendment Bill, the Bill would provide a fast-lane citizenship application process for Hindu, Buddha, Jain, Sikh, Parsi, and Christian refugees from neighboring Muslim countries in South Asia. Narendra Modi argued that the Bill was being proposed to fulfill Nehru's wishes to amend existing legislation regarding the acceptance of religious minorities from neighboring countries (Scroll. in, 2020). This Bill aimed to provide more protection to religious minorities persecuted for years in Muslim-majority countries of Afghanistan, Bangladesh and Pakistan who shared direct borders with India. The ruling BJP government also repeated the argument that in the early years after the Partition, the leaders of India and Pakistan had signed the Liaquat-Nehru Pact (also known as the Delhi Pact). Liaquat-Nehru Pact had agreed-upon rules on the rights of returning refugees and their rights to their property being left during the Partition years. Liaquat-Nehru Pact also emphasized the role of the government of India and Pakistan to oversee the protection of religious minorities against any persecution and discrimination. Ministry of Home Affairs of the Government of India, Amit Shah also criticized the lack of protection towards the religious minorities by Afghanistan, Pakistan and Bangladesh that causes 20 percent decline in religious minorities in these countries, which eventually propelled the BJP government to expedite the process 
of providing citizenship status (ANI, 2020).

The Citizenship Amendment Bill was also accompanied by implementing the stricter National Registry of Citizenship (NRC) policy. This new stricter rule will include preparing a new list of National Population Registry (NPR) projects. Based on the new database created under the new NPR, the government of India will be able to indicate the legal status of every people living in India. While the CAA allows religious minorities to find shelter in India, NPR and NRC could consider several communities in India which did not possess any legal status as "illegal". Consequently, these "illegal communities" will be deported back to their "place of origins". The acceptance of the Bill and its subsequent enactment as an Act has caused many negative consequences, especially in making Muslims 'other' and 'second-class citizens' in a quasi-secular India (Bhat, 2019). The high-ranking politicians from BJP defended that the Act would not deliberately discriminate against the rights of Indian Muslims, as it will only affect those with legal complications related to their residential status (Hindustan Times, 2020; Venkataramakrishnan, 2020). This claim was then contested by various political oppositions, human rights organizations and experts saying that the CAA is intended to exclude Indian Muslims from public life, especially those who had migrated to India decades before but did not able to acquire legal status due to several administrative obstacles (Human Rights Watch, 2020). These 'to-be' expelled Muslims would be replaced by 'potentially loyal' adherents of Indic religions.

The underlying motives behind the policy of the Indian government to expedite the citizenship process for the religious minorities from Afghanistan, Pakistan, and Bangladesh could be seen as an effort to strengthen its true 'Self' against the potential 'Other' who might be able to disturb the integrity of the 'Self'. In the perspective of Hindu Nationalists, a Dharma-based stable social order could only be achieved through the realization of viraha (longing of the Divided Self) and duhkha (suffering of the Self) as a by-product of the Partition. The Partition had broken the vision of Akhand Bharat, of an India united in terms of religious belief and culture. In the perspective of Hindu nationalists, the Indian Self is suffering from longing to unite with the fellow believers of Indic religions 
who are also experiencing duhkha as religious minorities in Muslim majority countries of Afghanistan, Pakistan and Bangladesh.

The BJP government is following this logic of Hindu political theology to legitimize their policy and action towards religiously persecuted minorities, even in the price of possibly sacrificing the rights of "illegal" Indian Muslim minorities. Unfortunately, the BJP government is still yet to find its moment of samvega (discovery of the Self through duality shock), enabling them to empathize and alleviate the sufferings of not only the adherents of Indic religions but also of persecuted Muslims. However, in the Citizenship Amendment Act (CAA)), the Indian government has not made significant progress to expedite the citizenship registration process. Due to legal and administrative complications, many migrants from the adherents of Indic religions still have not acquired legal status.

Therefore, in the case of the, it can be seen that despite the natural diversity that India currently owns, the current BJP government is unwilling to open an honest discussion on ways to construct a more pluralistic conception of Indian citizenship. Instead, the
BJP government opted for the homogenization of the society based on the Hindutva model of an ideal citizen. Consequently, this situation closed many possibilities of further dialogues on the concept of citizenship, and eventually, principled pluralism will need more time to be implemented in India. Continuous resistance from democratic and religious political forces could be the key to achieving the principled pluralism that will determine India's democratization course.

In contemporary Turkey, as Turkey established, it is new that slightly transformed the boundaries between religion and politics in its homeland, many Arab countries experienced a wave of democratization brought by the Arab Spring. Arab Spring has introduced many Arab countries to the Turkish model of democratization. In this case, Turkey started to show itself as a leader and role model for Arab and Muslim countries. But, when Turkey experienced mass protests during the Gezi Park movement, many questioned Turkish credentials as a democratic country. Eventually, Turkey finds another way to strengthen its own 'conservative democracy' narrative in the Middle East by involving the Syrian crisis, 
both politically and militarily (Keyman, 2016) Turkish active involvement in Syria was based on not only the security consideration but also political considerations. Turkey wanted to expand and exert its geopolitical influences beyond its border by reinforcing the idea of 'Muslim democracy' throughout the Middle East and the larger Muslim World.

Turkey's 'open door' policy was in line with the Turkish plan to strengthen its leadership amongst Sunni Muslim countries in the Middle East and the World. By invoking the narratives of 'Bizler Ensar, sizler muhacir (We are the guarantor, and you are the persecuted), the AK Parti government under Erdogan's leadership is trying to position itself as a guarantor (ensar) of the persecuted Arab-MuslimSunnite populace (muhacir) from the authoritarian Syrian regime (SABAH, 2014). In this context, the Turkish government considered the authoritarian Syrian regime could be considered as similar to the Quraish community in the era of Prophet Muhammad. Even though Syrian (and Iraqi) refugees had various ethnic and religious backgrounds, Korkut (2016) argued that the AK Parti government had maintained a pragmatic and selective approach to treating the incoming refugees. Preferential treatments were mostly provided to the Arab-MuslimSunnite refugee populations, most discriminated against and suffered from Assad's authoritarian regime.

However, as Getmansky, Sinmazdemir, and Zeitzoff (2018) explained, the Turkish public (especially Turkish citizens of Turkic origin) was negatively reacting to a supposedly welcoming attitude of the AK Parti government toward the Syrian refugees. The negative reactions reached their climax when the AK Parti government promised to grant citizenship to the Syrian refugee once they had stayed in the countries for a certain period. Gülmez (2019) showed that several Turkish parties were trying to securitize the Syrian refugee issue either by deploying the issue of Turkic nationalist identity (in the case of right-wing Milliyetci Hareket Partisi or MHP) and the issue of crime and unemployment (in the case of center-left Cumhuriyet Halk Parrtisi or CHP). It is also worth noting that even the acceptance of Arab-Muslim-Sunnite refugees could be recognized as partial. Gökarıksel and Secor (2020) noted that Arab-Muslim-Sunnite refugees are still experiencing anxiety and 
pain in their daily life as a refugee in Turkey. This finding is also confirmed by Gümüş and Eroğlu (2015)they were subsequently granted the official status of 'temporary protection'. The article also covers efforts to incorporate the Syrians into some areas of Turkish society (the job market, healthcare, citizenship, the housing market, social prominence and marriage relationships, who argued that the incorporation of Syrian in some areas of Turkish society had not been addressed improperly due to the legal complexity over the status of Syrian migrants in Turkey and, subsequently, the domestic political debates in Turkey over the Syrian migrant's legal status/

This phenomenon proves that the AK Parti government is trying to follow its interpretation of Sunni political theology principles based on Muslim unity, which will be realized under the Turkish leadership. The project to rebuild a new conception of Turkish citizenship based on the incorporation of Arab-MuslimSunnite refugees could not be called successful, as there are still debates among Turkish society whether the Arab-Muslim-Sunnite Syrian and Iraqi migrants could be accepted as a Turkish citizens. The rise of nativism and lack of multicultural understanding in Turkish society within the existing construct of the new conception of Turkish citizenship might be the biggest challenge that inhibits Turkey from achieving principled pluralism ideals.

\section{CONCLUSION}

This paper has discussed the influence of political theology on Indian and Turkish foreign policies, especially in the humanitarian crisis. It can be noted that both India and Turkey are two countries that experienced secularisation and modernization, complicating the quest to discover the true Self of both countries. Once populist regimes that subscribed to rightwing political values were brought to power, India and Turkey subsequently constructed a new political understanding that entails the importance of conservatism based on religious values. In the case of India, the Hindutva political vision put forward by the BJP government has become one of the main drives of policy-making. Even though the influence of Hindutva values in the Indian foreign policy is still debated, it is clear that in the case of the Citizenship Amendment Act (CAA) and subsequent policies are constructed within a vision to enable 
the unity of Hindus in the Indian subcontinent and the domination of Hindu rule. India, under the government BJP, considered itself as a savior for the religiously persecuted minorities. The BJP government also tried to strengthen its true Self by emphasizing the suffering of the religious minorities in neighboring countries. Ironically, the claim for the true Self must sacrifice its commitment to protecting another important part of religious minorities, that is, the Muslim community. India's effort to find its true Self is distracted because of the unwillingness to accept the existence of Muslim refugees in India. The discovery of the true Self of India would be very much dependent on how India would reconcile with its "divided nature" of its Self through honest discussions and public deliberations, which are the backbones of principled pluralism.

In the case of Turkey, the ancien regime of Turkish laicism was put under criticism by the AK Parti regime, which claimed to carry the popular will to establish a new regime that respects both democracy and Turkish conservative values. Various research has shown that there is a direct connection between the new orientation of Turkish foreign policy. The influence of "conservative democracy" and "moral realism" values in Turkish foreign policy could be seen clearly in the Syrian refugee crisis. During the crisis, Turkey has implemented an open-door policy and tried to show itself as a savior for the persecuted people coming from Syria. Turkey decided to implement a policy of favoring Arab-MuslimSunnite Syrian refugees. Turkey would like to reaffirm its Self as the protector and the leader of the Sunni Muslim world.

Moreover, the AK Parti government was willing to provide Turkish citizenship to the ArabMuslim-Sunnite Syrian refugees as part of their actions to strengthen their credentials as leaders of the global Sunni Muslim community. Nevertheless, many Turkish political parties were opposed to the plans brought by the AK Parti government, citing the issue of rising crime allegedly brought by Syrian refugees and the integrity of Turkish national identity. The effort to achieve the politics of principled pluralism in Turkey during the momentum of the humanitarian crisis will need commitment from the AK Parti itself and the opposition parties. 


\section{REFERENCES}

Alam, A. (2009). Islam and PostModernism: Locating The Rise of Islamism in Turkey. Journal of Islamic Studies, 20(3), pp. 352-375.

Altunışık, M. (2005). The Turkish model and democratization in the Middle East, Arab Studies Quarterly, 27(1/2), pp. 45-63.

ANI. (2020). 20\% decline in religious minorities in Pakistan, Bangladesh: Shah in RS after tabling $\mathrm{CAB}$. Retrieved December 15, 2020, from https://www.aninews.in/news/ national/politics/20-declinein-religious-minoritiesin-pakistan-bangladeshshah-in-rs-after-tablingcab20191211123536/

Azak, U. (2008). Secularism in Turkey as a Nationalist Search for Vernacular Islam: The Ban on the Call to Prayer in Arabic (1932-1950). Revue Des Mondes Musulmans et de La Méditerranée, 124, pp. 161179. https://doi.org/10.4000/ remmm. 6025

Bhat, M. M. A. (2019). The constitutional case against the Citizenship Amendment Bill. Economic and Political Weekly, IIV(3), pp. 12-14
Bhatt, C., \& Mukta, P. (2000). Hindutva in the West: Mapping the antinomies of diaspora nationalism. Ethnic and Racial Studies, 23(3), pp. 407-441. https://doi. org/10.1080/014198700328935

Çelik, N. (2018). From secularism to laïcité and analyzing Turkish authoritarian laiklik. Insight Turkey, 20(1), pp. 189-208. https://doi. org/10.25253/99.2018201.11

Clarke, S. (2002). Hindutva, religious and ethnocultural minorities, and Indian-Christian theology. Harvard Theological Review, 95(2), pp. 197-226. https://doi.org/10.1017/ s0017816002000123

Fuat Keyman, E. (2016). Turkish foreign policy in the post-Arab Spring era: from proactive to buffer state. Third World Quarterly, 37(12) pp. 22742287. https://doi.org/10.1080/0 1436597.2016.1199260

Getmansky, A., Sinmazdemir, T., \& Zeitzoff, T. (2018). Refugees, xenophobia, and domestic conflict: Evidence from a survey experiment in Turkey. Journal of Peace Research, 55(4), pp. 491507. https://doi.org/10.1177/ 0022343317748719 
Gökarıksel, B., \& Secor, A. J. (2020). Affective geopolitics: Anxiety, pain, and ethics in the encounter with Syrian refugees in Turkey. Environment and Planning C: Politics and Space, 38(7-8), pp. 12371255. https://doi.org/10.1177/ 2399654418814257

Golwalkar, M. S. (1939). We or Our Nationhood Defined. Nagpur: Bharat Publications.

Guida, M. (2014). Nurettin Topçu and Necip Fazıl Kısakürek: Stories of 'Conversion' and Activism in Republican Turkey. Journal of Islamic Studies, 34(1), pp. 1176-1198.

Gülmez, R. (2019). The Securitization of the Syrian Refugee Crisis Through Political Party Discourses. Journal of International Migration and Integration. https://doi. org/10.1007/s12134-018-06372

Gümüş, B., \& Eroğlu, D. (2015). Partial integration of Syrian 'escapees' under the rule of Turkey's Justice and Development Party (JDP). Contemporary Arab Affairs, 8(4), pp. 469-487. https://doi. org/10.1080/17550912.2015.10 80965
Haynes, J. (2014). An Introduction to International Relations and Religion. In An Introduction to International Relations and Religion. London: Routledge. https://doi. org/10.4324/9781315833026

Hindustan Times. (2020). 'BJP has not put up a "no exit" board": Naqvi on Muslim leaders quitting party over CAA. Retrieved December 15, 2020, from Hindustan Times website: https://www.hindustantimes. com/india-news/bjp-hasnot-put-up-a-no-exit-boardnaqvi-on-muslim-leadersquitting-party-over-caa/ story-3dP8uGxjG5mxUF1tosePjN. html

Human Rights Watch. (2020). "Shoot the Traitors": Discrimination Against Muslims under India's New Citizenship Policy. New York.

Joustra, R. (2018). The Religious Problem with Religious Freedom: Why Foreign Policy Needs Political Theology. Oxon. and New York: Routledge.

Kaya, A., Robert, M. V., \& Tecmen, A. (2020). Populism in Turkey and France: nativism, multiculturalism and Euroskepticism. Turkish 
Studies. https://doi.org/10.1080 /14683849.2019.1637260

Khan, T. (2020). The Citizenship Amendment Act, 2019: A Religion Based Pathway to Indian Citizenship. SSRN Electronic Journal. https://doi. org/10.2139/ssrn.3665743

Kloos, S. (2016). The Neo-Ottoman Turn In Turkey's Refugee Reception Discourse. Alternatif Politika, 8(3), pp. 537-561

Korkut, U. (2016). Pragmatism, moral responsibility or policy change: the Syrian refugee crisis and selective humanitarianism in the Turkish refugee regime. Comparative Migration Studies, 4(2), pp. 1-20. https://doi. org/10.1186/s40878-015-00209

Kuru, Z. A., \& Kuru, A. T. (2008). Apolitical interpretation of Islam: Said Nursi's faithbased activism in comparison with political Islamism and Sufism. Islam and Christian-Muslim Relations. https://doi.org/10.1080/ 13510340701770311

Mardin, Ş. (2005). Turkish Islamic Exceptionalism Yesterday and Today: Continuity, Rupture and Reconstruction in Operational Codes. Turkish Studies,
6(2), pp. 145-165. https:// doi.org/10.1080/146838 40500119478

MHA Government of India. Flag Code of India. (2002).

Öztürk, A. E. (2019). An alternative reading of religion and authoritarianism: the new logic between religion and state in the AKP's New Turkey. Journal of Southeast European and Black Sea. https://doi.org/10.1080/14 683857.2019.1576370

SABAH. (2014). Cumhurbaşkanı Erdoğan: Bizler Ensar sizler muhacir.

Scroll.in. (2020). CAA: 'Was Nehru communal for wanting to protect minorities of Pakistan?' Modi asks in Parliament. Retrieved December 15, 2020, from https://scroll.in/latest/952328/ ram-temple-matter-would-nothave-been-resolved-if-centrehad-followed-old-policies-pmmodi

Sharma, S. K., \& Nain, A. (2018). Integral Humanism of Deen Dayal Upadhyaya and Its Contemporary Relevance. The Indian Journal of Political Science, LXXIX(1), 13-20.

Tepe, S. (2016). Contesting political theologies of Islam and democracy in Turkey. Journal of 
Religious and Political Practice. https://doi.org/10.1080/205660 93.2016.1181386

Vajpeyi, A. (2012). Righteous Republic. Cambridge, MA and London, England: Harvard University Press. https://doi.org/10.4159/ harvard.9780674067288

Venkataramakrishnan, R. (2020). BJP insists Indian Muslims have nothing to fear from CAA - so why are people still protesting? Retrieved December 15, 2020, from https://scroll.in/ article/955649/bjp-insistsindian-muslims-have-nothingto-fear-from-caa-so-why-arepeople-still-protesting

Weiker, W. F. (1968). The Ottoman Bureaucracy: Modernization and Reform. Administrative Science Quarterly, 13(3). 